\title{
South and Central America Cut Flower Production and Postharvest Survey
}

\author{
Cristian E. Loyola ${ }^{1}$, John M. Dole ${ }^{1}$, and Rebecca Dunning ${ }^{1}$
}

AdDITIONAL INDEX wORDs. carnation, chrysanthemum, diseases, hydration, insects, rose, temperature, timing

SUMMARY. Imports of cut flowers into the United States have doubled in the last 20 years and come mainly from Colombia and Ecuador. We surveyed the cut flower industry in South and Central America, focusing on Colombia and Ecuador, to determine their production and postharvest problems. We received a total of 51 responses, of which $62 \%$ of the respondents had 100 or more employees. The most commonly grown or handled crops were rose (Rosa hybrids), carnation (Dianthus caryophyllus), chrysanthemum (Chrysanthemum $\times$ grandiflorum), alstroemeria (Alstroemeria cultivars), gerbera (Gerbera jamesonii), and hydrangea (Hydrangea species), in order of ranking. The most significant production problem was insect management, with disease management and crop timing the next most important issues. The most important species-specific issues in production were phytosanitary problems, disease (causal organism not specified), leaf miner (Lepidoptera, Symphyta, or Diptera), and thrips (Thysanoptera). The main overall postharvest problem was temperature management, followed by hydration and flower food management and botrytis (Botrytis cinerea). In regard to on-farm postharvest handling, damage to the flowers was the most mentioned issue. For the postharvest during storage and transport phase, temperature management, air transport, damage, and botrytis were the most important problems. The most mentioned customer complaints were damage, botrytis, and phytosanitary problems. The results of this survey can be used by researchers to focus their work on topics of most need. Improved production and postharvest handling will support the continued growth of the cut flower industry.

$\mathrm{T}$ oday's cut flower industry is globalized. In the United States, imports of cut flowers began in the 1960s (Conlon, 2016). Over the last 20 years, cut flower exports have more than doubled in size from about $\$ 4$ billion in 1995 to more than $\$ 8$ billion by 2015 (Simoes and Hidalgo, 2011). The cut flower industry is highly dynamic; the cultivars, production techniques, markets, and retailers are continuously changing. This dynamism challenges the adaptive abilities of producers and postharvest handlers involved in this business (van Liemt, 1999) and demands more research and development.

Received for publication 9 Aug. 2019. Accepted for publication 3 Sept. 2019

Published online 21 October 2019

${ }^{1}$ Department of Horticultural Science, North Carolina State University, 2721 Founders Drive, Raleigh, NC 27695-7609

This paper is a portion of a thesis submitted by C.E.L. in fulfilling the Masters of Horticultural Science degree requirement.

J.M.D. is the corresponding author. E-mail: jmdole@ ncsu.edu.

This is an open access article distributed under the CC BY-NC-ND license (https://creativecommons.org/ licenses/by-nc-nd/4.0/).

https://doi.org/10.21273/HORTTECH04484-19
Cut flowers are a highly perishable commodity, which are often traded over long distances because the centers of production are located mostly near the equator-while the main consumers are in Europe and North America (Dehnen-Schmutz et al., 2010; van Liemt, 1999). The United States currently is the biggest importer of cut flowers in the world, obtaining the majority of its flowers from producers in nearby countries: 81\% from South American countries and $9.5 \%$ from North and Central American countries (Simoes and Hidalgo, 2011; van Rijswick, 2016). Rose (Table 1 ) is the most important cut flower imported into the United States, followed by carnation, chrysanthemum, alstroemeria, and baby's breath, in order of importance, by production volume.

The authors completed surveys of the cut flower industries in the United States and Canada (Loyola et al., 2019) and noted the need to do similar surveys on the cut flower industries of South and Central America. The purpose of the current study is to assess the major production and postharvest issues that affect the cut flower industries in South and Central America. This work will provide a guide for industry and academic researchers regarding the most important issues to be addressed.

\section{Materials and methods}

A questionnaire was constructed in both Spanish and English and delivered using online software (Survey Monkey, San Mateo, CA), as done by Loyola et al. (2019). The questionnaires were emailed to the members of Asociación Colombiana de Exportadores de Flores (Asocolflores) in Colombia by Asocolflores number distributed is unknown); to 128 members of Expoflores in Ecuador; to 25 members of Agexport in Guatemala; and to 20 members of Asociación de Productores y Exportadores de Flores de Chile (APEF). The survey asked the business location, approximate size (based on number of full-time employees) and type of business, crops produced and/or handled, and production and postharvest problems across all crops and specifically for each of 21 crop species. Data were collected from Apr. to May 2018 in Colombia and from June to July 2018 in the rest of the countries.

Respondents were provided lists of 11 production and 8 postharvest issues and asked to select the most important issues for their business and score them from 1 to 5 , with 1 representing the most important problem (most severe) and 5 representing the least important problem for their business. Out of the 51 respondents, $55 \%$ of respondents completed the production problems question, and $61 \%$ answered the postharvest issues question. We also asked the respondents their specific production challenges, postharvest challenges, and customer complaints for 21 individual crop species. The species-specific postharvest problems were further divided into postharvest problems on the farm, problems

\begin{tabular}{llll}
\hline $\begin{array}{l}\text { Units } \\
\text { To convert U.S. to SI, } \\
\text { multiply by }\end{array}$ & U.S. unit & SI unit & $\begin{array}{l}\text { To convert SI to U.S., } \\
\text { multiply by }\end{array}$ \\
\hline$\left({ }^{\circ} \mathrm{F}-32\right) \div 1.8$ & ${ }^{\circ} \mathrm{F}$ & ${ }^{\circ} \mathrm{C}$ & $\left({ }^{\circ} \mathrm{C} \times 1.8\right)+32$
\end{tabular}


Table 1. Taxonomic classifications of organisms discussed in this article about South and Central American cut flower production and postharvest issues.

\begin{tabular}{|c|c|}
\hline Common name & Taxonomic nomenclature \\
\hline \multicolumn{2}{|l|}{ Diseases } \\
\hline Botrytis & Botrytis cinerea \\
\hline Downy mildew & Peronosporaceae \\
\hline Erwinia & Erwinia species \\
\hline Fusarium & Fusarium oxysporum \\
\hline \multicolumn{2}{|c|}{$\begin{array}{l}\text { Mildew (see downy mildew and powdery } \\
\text { mildew) }\end{array}$} \\
\hline Powdery mildew & Erysiphales \\
\hline Sigatoka & Mycosphaerella fijiensis \\
\hline White rust & Puccinia horiana \\
\hline \multicolumn{2}{|c|}{ Insects and related organisms } \\
\hline Leaf miners & Lepidoptera, Symphyta, Diptera \\
\hline Spider mite & Tetranychus species \\
\hline Thrips & Thysanoptera \\
\hline Whitefly & Aleyrodidnae \\
\hline \multicolumn{2}{|l|}{ Plants } \\
\hline Alstroemeria & Alstroemeria cultivars \\
\hline Anthurium & Anthurium hybrids \\
\hline Aster & Aster hybrids \\
\hline Baby's breath & Gypsophila elegans \\
\hline Bird of paradise & Strelitzia reginae \\
\hline Calla & Zantedeschia cultivars \\
\hline Carnation & Dianthus caryophyllus \\
\hline Chrysanthemum & Chrysanthemum $\times$ grandiflorum \\
\hline Cockscomb & Celosia argentea var. cristata \\
\hline Daffodil & Narcissus pseudonarcissus \\
\hline Delphinium & Delphinium hybrids \\
\hline Freesia & Freesia hybrids \\
\hline Garden roses & Rosa cultivars \\
\hline Gerbera & Gerbera jamesonii \\
\hline Hydrangea & Hydrangea species \\
\hline Liatris & Liatris spicata \\
\hline Lily & Lilium hybrids \\
\hline Oriental lily & Lilium Oriental hybrids \\
\hline Rose & Rosa hybrids \\
\hline Snapdragon & Antirrhinum majus \\
\hline Statice & Limonium cultivars \\
\hline Stock & Matthiola incana \\
\hline Sunflower & Helianthus annums \\
\hline Tulip & Tulipa gesneriana \\
\hline Zinnia & Zinnia violacea \\
\hline
\end{tabular}

during storage and transportation, and customer complaints.

\section{Results and discussion}

We received a total of 51 responses. Thirty-seven percent of the respondents had 200 or more employees, 25\% had 100 to $199 \mathrm{em}$ ployees, 16\% had 50 to 99 employees, $10 \%$ had 1 to 9 employees, $10 \%$ had 10 to 19 employees, and $2 \%$ had 20 to 49 employees. Forty-five percent of the respondents were the general managers of the company, $12 \%$ were the owners, $8 \%$ were sales
Table 2. Respondents to the 2018 survey regarding South and Central America cut flower production and postharvest issues were asked to report their job position with their company $(\mathbf{n}=\mathbf{5 1})$.

\begin{tabular}{lc}
\hline Job position & Respondents (\%) \\
\hline General manager & 45 \\
Owner & 12 \\
Production manager & 8 \\
Postharvest manager & 8 \\
Sales representative & 8 \\
Floral designer & 4 \\
Agronomist & 2 \\
Other & 13 \\
\hline
\end{tabular}

Ecuador, 4 in Chile, 1 in Guatemala, and $\mathrm{l}$ in Peru.

Most respondents, $58 \%$, reported producing or handling only one crop species, and only $7 \%$ reported growing six or more crops (Fig. 1). In contrast, cut flower businesses produce and handle a much broader array of crops in the United States and Canada (Loyola et al., 2019). Of the 210 respondents in the Loyola et al. (2019) survey, only 9\% reported producing 1 to 3 crops; $5 \%$ produced 4 to 6 crops; while $86 \%$ of respondents produced or handled 7 or more crops, with almost one-third growing 13 to 18 different crops.

The three most commonly produced crops were carnation, chrysanthemum, and rose, which also had numerous production and postharvest issues reported due to the large number of responses (Tables 3 and $4)$. The less commonly produced crops and those with less than five respondents per species were grouped together for the presentation of the production and postharvest issues (Tables 3 and 5). Of the top 10 crops-alstroemeria, aster, bird of paradise, carnation, chrysanthemum, gerbera, hydrangea, daffodil, rose, and statice - in the South and Central American survey, only hydrangea and statice were among the top 31 crops grown by U.S. and Canadian growers (Loyola et al., 2019). Rose was also among the top 31 crops in the United States and Canada, but producers in those countries mainly grow fieldgrown garden roses, while producers in South and Central America mainly grow hybrid tea roses under cover (Dole et al., 2017; Hamrick, 2003). 


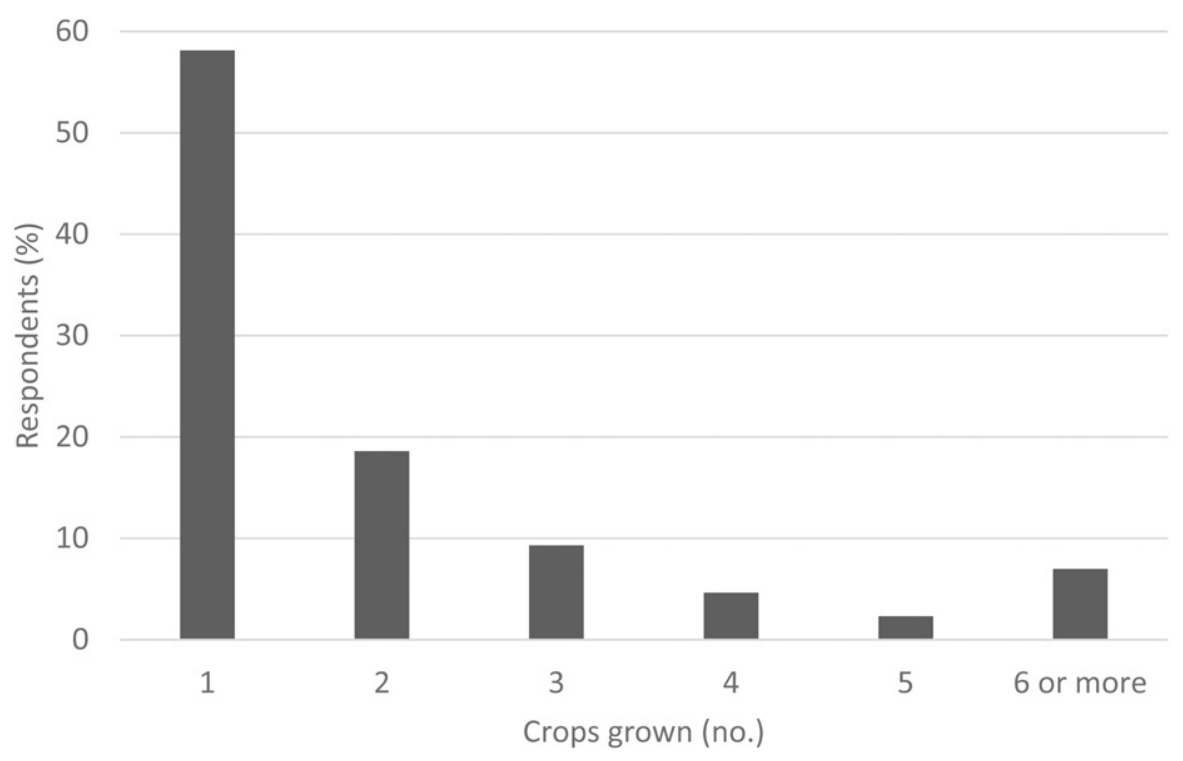

Fig. 1. Respondents to the 2018 survey regarding South and Central America cut flower production and postharvest issues were asked to mark the number of crops they produced. The graph shows the number of different crops produced by each respondent as a percent of total responses $(n=43)$.

Table 3. Respondents to the 2018 survey regarding South and Central America cut flower production and postharvest issues were provided with a list of 21 cut flower crops and asked to mark those species that they produce. Crops are ranked in order from most commonly to least commonly grown $(\mathbf{n}=\mathbf{5 1})$.

\begin{tabular}{lc}
\hline Species & Respondents (\%) \\
\hline Rose & 47 \\
Carnation & 20 \\
Chrysanthemum & 16 \\
Alstroemeria & 14 \\
Gerbera & 12 \\
Hydrangea & 12 \\
Bird of paradise & 6 \\
Statice & 6 \\
Aster & 4 \\
Daffodil & 4 \\
Delphinium & 4 \\
Baby's breath & 4 \\
Liatris & 4 \\
Lily & 4 \\
Snapdragon & 4 \\
Sunflower & 4 \\
Anthurium & 2 \\
Calla & 2 \\
Freesia & 2 \\
Stock & 2 \\
Tulip & 2 \\
\hline
\end{tabular}

Alstroemeria, aster, chrysanthemums, and daffodil were grown by small numbers of producers in the United States and Canada. schedules and possibly missing peak sales periods.

Temperature management, insufficient demand, and poor-quality propagation materials were ranked as the least important issues (Fig. 2). However, six respondents reported temperature management and insufficient demand as their most important issue (a ranking of 1 ). Controlling temperature is related to crop timing and is important in ensuring a continuous supply and a sufficient production for important holidays, such as the production of roses for Valentine's Day. Of course, product demand is central to any business, and fluctuating demand can be a major issue for some businesses. The remaining production issues were of intermediate importance.

The most significant species-specific production problems were phytosanitary, disease, leaf miner, and thrips (Tables 4 and 5). For the three most commonly grown crops, phytosanitary problems were an issue in the production of rose $(21 \%$ of the respondents), carnation (20\%), and chrysanthemum (17\%). Phytosanitary problems refer to the contamination of the flowers with pathogens, insects, or other substances. The Agreement on the Application of Sanitary and Phytosanitary Measures of the World Trade Organization exists to protect the human, animal, or plant life or health during the trade of goods (World Trade Organization, n.d.). Due to this agreement, flowers cannot enter the United States if they are contaminated and could harm a local human, animal, or plant. The regulations are administered by USDA.

Disease management was a species-specific problem in the production of chrysanthemum (17\%) and rose $(16 \%)$ (Table 4$)$. In roses, respondents mentioned botrytis as a common disease (16\%), as well as downy and powdery mildew (5\% each) (Table 4). In chrysanthemum production, multiple other diseases were mentioned, including fungus, Tomato spotted wilt virus (TSWV), viroids, and white rust, while fusarium was reported for carnation. Disease (unspecified) was also mentioned as an important problem in the production of alstroemeria and hydrangea by one respondent for each species (Table 5). 
Table 4. Respondents to the 2018 survey regarding South and Central America cut flower production and postharvest issues were asked to identify their production challenges with 21 crop species, of which the top three species [carnation $(n=10)$, chrysanthemum $(n=8)$, and rose $(n=25)$ ] are listed in this table (see Table 5 for remaining species). The number listed is the percentage of respondents who reported the issue for each species. Some respondents reported multiple production issues for a species.

\begin{tabular}{|c|c|c|c|}
\hline Issue & Carnation & Chrysanthemum & Rose \\
\hline \multicolumn{4}{|c|}{ Respondents reporting production challenge (\%) } \\
\hline Affordability of labor & - & - & 5 \\
\hline Availability of qualified labor & - & - & 11 \\
\hline Blind shoots & - & - & 5 \\
\hline Cost & - & - & 5 \\
\hline Disease (did not specify disease) & - & 17 & 16 \\
\hline Botrytis & - & - & 16 \\
\hline Downy mildew & - & - & 5 \\
\hline Fungus & - & 17 & - \\
\hline Fusarium & 20 & - & - \\
\hline Powdery mildew & - & - & 5 \\
\hline Tomato spotted wilt virus & - & 17 & - \\
\hline Viroids & - & 17 & - \\
\hline White rust & - & 17 & - \\
\hline Fertilization & - & - & 5 \\
\hline Insects (did not specify insect) & - & 33 & - \\
\hline Leaf miner & 20 & 17 & - \\
\hline Spider mites & - & - & 16 \\
\hline Thrips & - & 17 & 11 \\
\hline Labor & 40 & - & - \\
\hline Labor work ethic & - & - & 5 \\
\hline Low productivity & - & - & 5 \\
\hline Low quality & - & - & 5 \\
\hline Phytosanitary & 20 & 17 & 21 \\
\hline Productivity & - & 17 & - \\
\hline Pruning & - & - & 5 \\
\hline Small heads & 20 & - & - \\
\hline Thin stems & 20 & - & - \\
\hline Timing & - & - & 16 \\
\hline None & 0 & 0 & 0 \\
\hline No response & 0 & 0 & 5 \\
\hline \multicolumn{4}{|c|}{ Respondents reporting on-farm postharvest challenge (\%) } \\
\hline Availability of labor & 20 & - & - \\
\hline Availability of qualified labor & - & - & 5 \\
\hline Botrytis & - & - & 11 \\
\hline Damage & 20 & 17 & 16 \\
\hline Disease (did not specify disease) & 20 & - & 5 \\
\hline Harvest & - & - & 11 \\
\hline Hydration & - & - & 11 \\
\hline Labor & - & - & 21 \\
\hline Low quality & - & - & 5 \\
\hline Pests & - & - & 5 \\
\hline Processing & 20 & - & - \\
\hline Storage & - & 17 & - \\
\hline Temperature management & - & 67 & 5 \\
\hline Variability in response to fertiliza & & - & 5 \\
\hline Weather & - & - & 16 \\
\hline None & 20 & 0 & 11 \\
\hline No response & 20 & 17 & 0 \\
\hline \multicolumn{4}{|c|}{ Respondents reporting postharvest challenge during storage and transport (\%) } \\
\hline Air transport (handling) & - & 17 & 21 \\
\hline Availability of qualified labor & - & - & 5 \\
\hline Botrytis & - & 17 & 11 \\
\hline
\end{tabular}

(Continued on next page)
Leaf miners was a species-specific problem in the production of carnation $(20 \%)$, chrysanthemum (17\%), and baby's breath for one respondent (Tables 4 and 5). Thrips were an important issue in the production of rose $(11 \%)$, chrysanthemum (17\%), and gerbera for one respondent ( $\mathrm{Ta}$ bles 4 and 5 ). Thrips can be especially damaging because they transmit viruses such as TSWV. Spider mites were a production problem mentioned across multiple species but only in rose from the most commonly produced crops (16\%) (Tables 4 and $5)$. Other crops on which this problem was mentioned were aster, gerbera, and hydrangea.

Postharvest issues. The most important overall postharvest issue was temperature management (Fig. 3 ). Cut flowers must be cooled rapidly to reduce respiration rate, which diminishes metabolic activities, preserves carbohydrates, and extends postharvest life for most cut flowers and foliage. Precooling is an especially important step as it rapidly lowers the temperature before storage and transportation. Most cut flowers and foliage should be held between 2 to $3{ }^{\circ} \mathrm{C}$. Exceptions would be for those susceptible to cold damage, such as tropical species, which should be held above 12 to $16{ }^{\circ} \mathrm{C}$; and cockscomb, oriental lilies, and zinnias, which should be held at 4 to $7{ }^{\circ} \mathrm{C}$ (Dole et al., 2017; Sun and Brosnan, 1999).

Hydration and flower food management was the next most important issue (Fig. 3) and was similarly ranked second by the U.S. and Canadian cut flower industry (Loyola et al., 2019). Treating cut flowers with proper postharvest solutions is critical after harvest and as the flowers move through the marketing chain. Hydration solutions are used to promote water uptake and reduce microbial growth. Flower foods provide a carbohydrate source to encourage flower and bud opening, color development, and vase life extension (Bosma and Dole, 2002; Cho et al., 2001).

Botrytis was the third most important postharvest issue. The moist environment within boxes packed with flowers is conducive to botrytis development, which can occur rapidly if the flowers warm up at any time during the storage and shipping process. 
Table 4. (Continued) Respondents to the 2018 survey regarding South and Central America cut flower production and postharvest issues were asked to identify their production challenges with 21 crop species, of which the top three species [carnation $(n=10)$, chrysanthemum $(n=8)$, and rose $(n=25)$ ] are listed in this table (see Table 5 for remaining species). The number listed is the percentage of respondents who reported the issue for each species. Some respondents reported multiple production issues for a species.

\begin{tabular}{|c|c|c|c|}
\hline Issue & Carnation & Chrysanthemum & Rose \\
\hline Damage & 40 & - & 16 \\
\hline Hydration & - & - & 5 \\
\hline Packaging & - & - & 5 \\
\hline Paperwork & - & - & 5 \\
\hline Processing & 20 & - & 5 \\
\hline Temperature management & 40 & 67 & 47 \\
\hline None & 0 & 0 & 5 \\
\hline No response & 20 & 0 & 5 \\
\hline \multicolumn{4}{|c|}{ Respondents reporting customer complaint (\%) } \\
\hline Botrytis & 20 & 17 & 47 \\
\hline Burning of stem & - & 17 & - \\
\hline Damage/broken stems & 60 & 50 & 53 \\
\hline Disease (did not specify disease) & - & - & 5 \\
\hline Failure to open & - & 17 & - \\
\hline Harvest & - & - & 5 \\
\hline Hydration & - & - & 5 \\
\hline Leaf drop & - & - & 5 \\
\hline Low quality & - & - & 16 \\
\hline Packaging & - & - & 11 \\
\hline Phytosanitary & 20 & - & 16 \\
\hline Thrips & 20 & - & 5 \\
\hline Vase life & - & - & 5 \\
\hline None & 0 & 0 & 0 \\
\hline No response & 20 & 17 & 0 \\
\hline Total respondents with issues (no.) & 5 & 6 & 19 \\
\hline
\end{tabular}

The issues ranked least important were customer care of product, lack of profitability, and affordability of qualified labor (Fig. 3). However, three respondents reported lack of profitability and five respondents report affordability of qualified labor as their most important issue (a ranking of 1). The latter two issues affect profitability, and responses would likely vary with the market conditions and may have ranked higher in this survey if it had been conducted during an economic downturn. The remaining postharvest issues of availability of qualified labor and insect management were of intermediate importance.

Postharvest issues on the FARM. The most common speciesspecific postharvest issue on the farm was damage, which was mentioned for carnation (20\%), chrysanthemum (17\%), and rose (16\%) (Table 4). Damage refers to mechanical deterioration of the product. Damage was also mentioned in alstroemeria by one respondent (Table 5 ) As previously mentioned, producers in South and Central America export most of their cut flowers to North America (Simoes and Hidalgo, 2011; van Rijswick, 2016). Because damage may cause flowers to be unmarketable, they are packed in bunches, sleeved, and put in boxes that reduce movement and possible damage during transport (Reid, 2006).

Temperature management was a major issue in the postharvest of chrysanthemum (67\%) (Table 4). Temperature management is the most effective way to increase postharvest life of cut flowers and is most effective if the crops are immediately cooled after harvest and if the low temperature is maintained throughout processing and transportation (maintaining the cold chain). Transit vehicles must be cooled before the loading of product to avoid temperature increases, and the product should not be overpacked to allow for good air circulation (Kader, 2002). It is especially difficult to maintain the cold chain over long distances, because the flowers must be moved between vehicles and storage facilities, which provides opportunities for problems to arise.

Other problems in the production of carnation were disease (species not specified) (20\%), labor (20\%), and processing $(20 \%)$ (Table 4$)$. One respondent selected availability of labor as a problem for carnation and rose, as harvesting and grading are especially labor intensive.

Storage was mentioned as a problem with chrysanthemum (17\%) and tulip for one respondent (Tables 4 and 5 ). Chrysanthemum stems can be stored at 0 to $4{ }^{\circ} \mathrm{C}$ for up to 2 weeks without flower decline; nevertheless, the foliage can turn yellow before the flowers deteriorate, and the severity of this problem varies by cultivar (Dole et al., 2017). Tulips are best stored with the bulbs attached. If stored with bulbs, stems can last for 2 weeks at 0 to $2{ }^{\circ} \mathrm{C}$; without the bulbs attached they can last only for $5 \mathrm{~d}$ (Dole et al., 2017).

Labor (21\%), harvest (11\%), and hydration (11\%) were other problems mentioned in the postharvest handling of rose (Table 4). One of the issues about labor was the work ethic of the employees. Rose harvest varies by market and cultivar, but a good stage to harvest red and pink roses is when the sepals have flexed outwards and one to two petals have unfurled; yellow roses should be harvested slightly earlier, and white roses slightly later. Roses should be placed in water immediately upon harvest. Use hydration solutions with a $\mathrm{pH}$ of 3 , and recut stems before hydrating (Dole and Wilkins, 2005; Dole et al., 2017).

Postharvest issues During STORAGE AND TRANSPORT. The postharvest issues during storage and transport were similar to those mentioned for postharvest on the farm (Tables 4 and 5). Postharvest issues during storage and transportation included temperature management, air transport, damage, and botrytis. Temperature management was a problem for chrysanthemum $(67 \%)$, rose $(47 \%)$, and carnation $(40 \%)$. Temperature management was also mentioned for aster, gerbera, baby's breath, hydrangea, 
Table 5. Respondents to the 2018 survey regarding South and Central America cut flower production and postharvest issues were asked to identify their production challenges with 21 crop species, of which those species with fewer than five responses are listed in this table (see Table 4 for remaining species). Some respondents reported multiple production issues for a species.

\begin{tabular}{ll}
\hline Species (no. of responses) & \\
\hline & Production challenges
\end{tabular}

Anthurium (1)

Aster (2)

Baby's breath (1)

Bird of paradise (2)

Calla (1)

Delphinium (1)

Gerbera (2)

Hydrangea (4)

Liatris (1)

Lily (1)

Snapdragon (1)

Statice (1)

Sunflower (1)

Tulip (1)

Alstroemeria (3)

On-farm postharvest challenges

Anthurium (1)

Aster (2)

Baby's breath (1)

Bird of paradise (2)

Calla (1)

Delphinium (1)

Gerbera (2)

Hydrangea (4)

Issue
Cost

Disease (not specified)

Insects (not specified)

Temperature management

Weather

Insects (not specified)

Scorching

Spider mites

Fungus

Leaf miner

Weather

Lack of supply

Low sales price

Germination

Botrytis

Fungus

Spider mites

Thrips

Disease (not specified)

Lack of demand

Low technification

Powdery mildew

Pruning

Spider mites

Temperature management

Fungus

Crop rotation

Flower bud abortion

Timing

Fungus

Fungus

Temperature management

Humidity

Damage

Plant burglary

No response

Cost

Foliage decay

Disease (not specified)

Pests

Botrytis

Hydration

Insects (not specified)

Sigatoka

Fungus

Crooked stems

Packaging

Hydration

Low technification

Powdery mildew

Processing

Spider mites

(Continued on next page)
Lack of demand snapdragon, and tulip. As was previously discussed in the Postharvest Issues on the Farm section, temperature management becomes difficult to maintain over long shipping distances and, thus, is more noticeable during this part of the marketing chain.

Similarly, long shipping durations resulted in complaints about the handling provided during air transportation for rose $(21 \%)$ and chrysanthemum (17\%) (Table 4). Air transport was also an issue for alstroemerias and gerbera (Table 5). The respondents specifically mentioned that air transport companies break the cold chain and do not handle the product with care, which damages the flowers.

Damage was an important postharvest problem during storage and transport for carnation $(40 \%)$, rose (16\%), alstroemeria, and bird of paradise (Tables 4 and 5 ). This problem was previously discussed in the Postharvest Issues on the Farm section.

Botrytis was an important postharvest issue for chrysanthemum $(17 \%)$, rose $(11 \%)$, gerbera, and hydrangea (Tables 4 and 5). Botrytis is a common disease in cut flowers that can occur at any stage of production or marketing. It develops most quickly under warm temperatures and high humidity, which is why it tends to be a problem during storage and shipping (Williamson et al., 2007).

Customer complaints. The customer complaints most mentioned across various crops were damage, botrytis, and phytosanitary issues ( $\mathrm{Ta}$ bles 4 and 5 ). Damage was again mentioned in the customer complaints section for carnation $(60 \%)$, rose $(53 \%)$, chrysanthemum $(50 \%)$, bird of paradise, calla, gerbera, and hydrangea. Carnation stems tend to break at the nodes, and damage when carnations are received by the consumer may be related to improper postharvest handling of the crop during transport.

Phytosanitary problems were mentioned for carnation (20\%) and rose (16\%) (Table 4). As previously discussed, phytosanitary problems can result in the product being destroyed or subjected to costly fumigation by importing countries. Botrytis was an issue for carnation $(20 \%)$, chrysanthemum (17\%), rose (17\%), delphinium, and hydrangea. Thrips 
Table 5. (Continued) Respondents to the 2018 survey regarding South and Central America cut flower production and postharvest issues were asked to identify their production challenges with 21 crop species, of which those species with fewer than five responses are listed in this table (see Table 4 for remaining species). Some respondents reported multiple production issues for a species.

\begin{tabular}{|c|c|}
\hline Species (no. of responses) & Issue \\
\hline Lily (1) & None \\
\hline Snapdragon (1) & None \\
\hline Tulip (1) & Storage \\
\hline \multicolumn{2}{|c|}{ Postharvest challenges during storage and transport } \\
\hline \multirow[t]{3}{*}{ Alstroemeria (3) } & Air transport \\
\hline & Damage \\
\hline & None \\
\hline \multirow[t]{2}{*}{ Anthurium (1) } & Packaging \\
\hline & Processing \\
\hline Aster (2) & Temperature management \\
\hline Baby's breath (1) & Temperature management \\
\hline \multirow{2}{*}{ Bird of paradise (2) } & Damage \\
\hline & Lack of demand \\
\hline Calla $(1)$ & Erwinia \\
\hline \multirow[t]{3}{*}{ Gerbera (2) } & Air transport \\
\hline & Botrytis \\
\hline & Temperature management \\
\hline \multirow[t]{6}{*}{ Hydrangea (4) } & Humidity \\
\hline & Hydration \\
\hline & Labor intensive \\
\hline & Processing \\
\hline & Temperature management \\
\hline & Botrytis \\
\hline Lily (1) & None \\
\hline \multirow[t]{2}{*}{ Snapdragon (1) } & Humidity \\
\hline & Temperature management \\
\hline \multirow[t]{3}{*}{ Tulip (1) } & Processing \\
\hline & Temperature management \\
\hline & Customer complaints \\
\hline Alstroemeria (3) & Lack of supply \\
\hline Anthurium (1) & Flower size \\
\hline Aster (2) & Temperature management \\
\hline Baby's breath (1) & Petal browning \\
\hline Bird of paradise (2) & Damage \\
\hline \multirow[t]{2}{*}{ Calla (1) } & Damage \\
\hline & Rot \\
\hline Delphinium (1) & Botrytis \\
\hline Gerbera $(2)$ & Damage \\
\hline \multirow[t]{4}{*}{ Hydrangea (4) } & Damage \\
\hline & Humidity \\
\hline & Temperature management \\
\hline & Botrytis \\
\hline Lily (1) & None \\
\hline \multirow{2}{*}{ Snapdragon (1) } & Humidity \\
\hline & Hydration \\
\hline Tulip (1) & Vase life \\
\hline
\end{tabular}

was a major problem with carnations (Table 4).

Another customer complaint for chrysanthemums was failure to open (17\%) (Table 4). Cut flowers harvested in the bud stage tolerate handling and transportation better; but if the flowers are harvested too early, they may not develop or open properly (van Doorn and Kamdee, 2014). If flowers are received in the bud stage, they are generally treated with flower foods after receipt to encourage flower opening.

For rose, low quality (16\%) and packaging $(11 \%)$ were also listed in customer complaints (Table 4). As previously discussed, appropriate packaging is very important to maintain crop quality by minimizing movement and increasing air flow to allow faster cooling. Additionally, quality also depends on a variety of other factors, such as stage of harvest, insects, and diseases. Furthermore, some rose cultivars are ethylene sensitive (Dole et al., 2017; van Doorn and van Meeteren, 2003).

\section{Conclusions}

The most commonly grown or handled crops were rose, carnation, chrysanthemum, alstroemeria, gerbera, and hydrangea, in order of ranking. The three crops with the most responses for species-specific issues were carnation, chrysanthemum, and rose. This finding suggests that research should be primarily focused on these three crops. For carnation, labor requirements, mechanical damage, and temperature management were the most important issues; and for chrysanthemum, temperature management and mechanical damage were most commonly mentioned. The major issues with rose were phytosanitary issues, mechanical damage, temperature management, and botrytis.

The most important overall production problems were insect and disease management, with crop timing as the next most important issue. The most commonly reported species-specific production problems were phytosanitary problems, disease (not specified), leaf miner, and thrips.

The main overall postharvest problem was temperature management, followed by hydration, flower food management, and botrytis. The major postharvest problem on the farm was damage. The major postharvest problems during storage and transportation were temperature management, air transport, damage, and botrytis. The most important customer complaints were damage, botrytis, and phytosanitary problems.

\section{Literature cited}

Bosma, T. and J.M. Dole. 2002. Postharvest handling of cut Campanula flowers. HortScience 37:954-958.

Cho, M.C., F. Celikel, and L. Dodge. 2001. Sucrose enhances the postharvest quality of cut flowers of Eustoma 


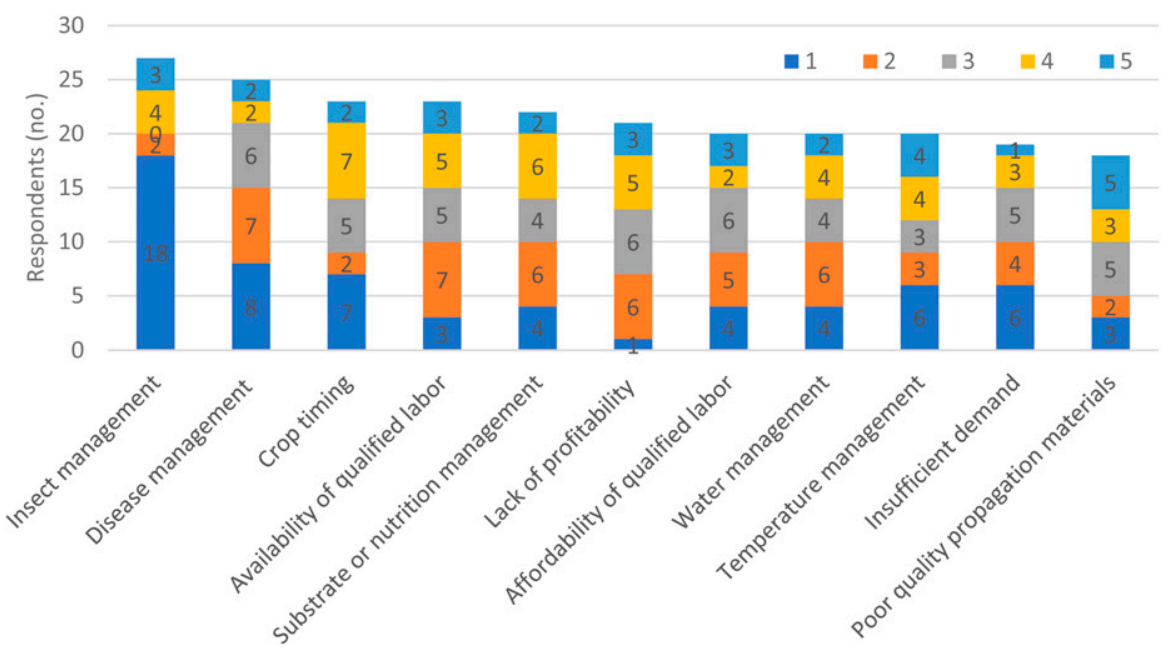

Fig. 2. Respondents to the 2018 survey regarding South and Central America cut flower production and postharvest issues were asked to select the most important production issues for their business and rank them from 1 to 5 , with 1 being the most important. Numbers in the bars are the number of times the ranking was recorded for each production issue $(n=28)$. Note that no respondents rated the issue of insect management a three.

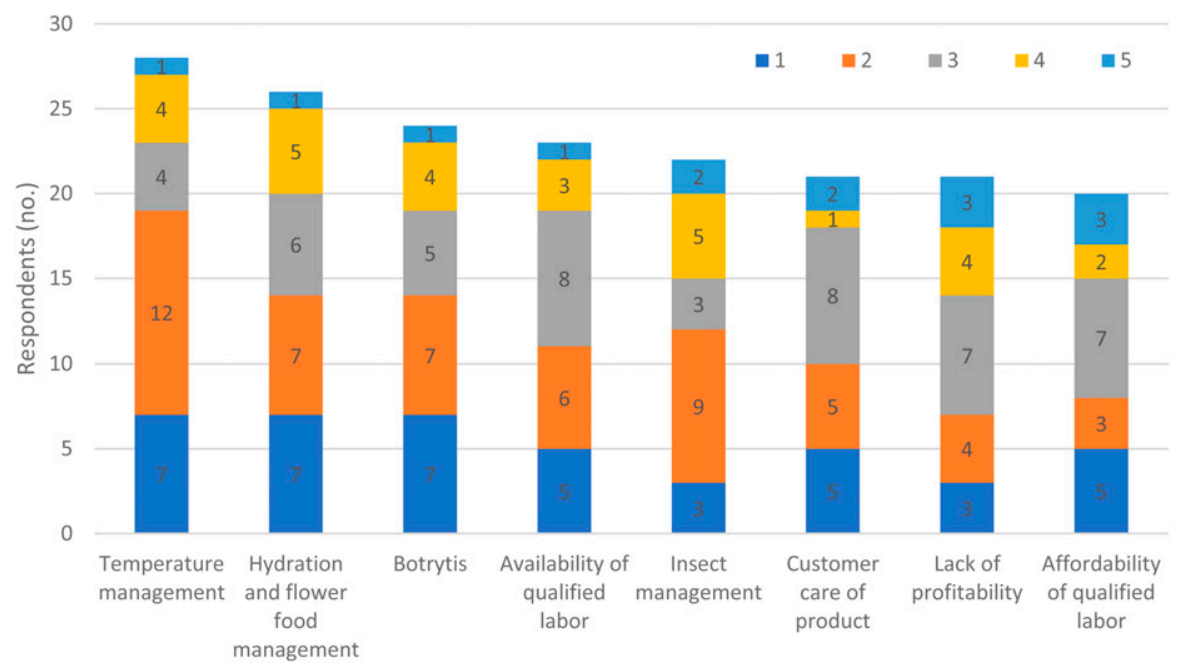

Fig. 3. Respondents to the 2018 survey regarding South and Central America cut flower production and postharvest issues were asked to select the most important postharvest issues for their business and rank them from 1 to 5 , with 1 being the most important. Numbers in the bars are the number of times the ranking was recorded for each production issue $(n=31)$.

grandiflora (Raf.). Shinn. Acta Hort. $543: 305-315$

Conlon, M. 2016. The history of the Colombian flower industry and its influence on the United States. U.S. Dept. Agr., Foreign Agr. Serv., Bogota, Colombia.

Dehnen-Schmutz, K., O. Holdenrieder, M.J. Jeger, and M. Pautasso. 2010. Structural change in the international
Specialty Cut Flower Growers, Oberlin, $\mathrm{OH}$.

Hamrick, D. 2003. Ball redbook, crop production. Vol. 2. 17th ed. Ball Publ., Batavia, IL.

Kader, A.A. 2002. Postharvest technology of horticultural crops. 3rd ed. Univ. California, Agr. Natural Resources Commun. Serv., Oakland, CA.

Loyola, C.E., J.M. Dole, and R. Dunning. 2019. North American specialty cut flower production and postharvest survey. Hort Technology 29:338-359.

Mercurio, G. 2007. Cut rose cultivation around the world. Schreurs, De Kwakel, The Netherlands.

Reid, M.S. 2006. Air transport of cut flowers. I Sept. 2019. <https://ucanr.edu/ datastoreFiles/234-1373.pdf>.

Simoes, A.J.G. and C.A. Hidalgo. 2011. The economic complexity observatory: An analytical tool for understanding the dynamics of economic development. 1 Sept. 2019. <https://atlas.media.mit.edu/en/ visualize/stacked/hs92/export/show/ all $/ 0603 / 1995.2015 />$

Sun, D. and T. Brosnan. 1999. Extension of the vase life of cut daffodil flowers by rapid vacuum cooling. Int. J. Refrig. $22: 472-478$

U.S. Department of Agriculture. 2009. Cut flowers and greenery import manual. 1 Sept. 2019. <https://www.hsdl.org/? view\&did $=29008>$.

van Doorn, W.G. and C. Kamdee. 2014. Flower opening and closure: An update. J. Expt. Bot. 65:5749-5757.

van Doorn, W.G. and U. van Meeteren. 2003. Flower opening and closure: A review. J. Expt. Bot. 54:1801-1812.

van Liemt, G. 1999. The world cut flower industry: Trends and prospects. Intl. Labour Office, Geneva, Switzerland.

van Rijswick, C. 2016. World floriculture map 2016: Equator countries gathering speed. Rabobank, Utrecht, The Netherlands.

Williamson, B., B. Tudzynski, P. Tudzynski, and J.A.L. Van Kan. 2007. Botrytis cinerea: The cause of grey mold disease. Mol. Plant Pathol. $8: 561-580$.

World Trade Organization. n.d. Understanding the WTO agreement on sanitary and phytosanitary measures. 1 Sept. 2019. <https://www.wto.org/english/tratop_e/ sps_e/spsund_e.htm>. 